\title{
EQUILIBRIUM
}

Quarterly Journal of Economics and Economic Policy

2015 VOLUME 10 ISSUE 4, December

p-ISSN 1689-765X, e-ISSN 2353-3293

www.economic-policy.pl

Pilc, M. (2015). What Determines the Reforms of Employment Protection Legislation? A Global Perspective. Equilibrium. Quarterly Journal of Economics and Economic Policy, 10(4), pp. 111-129, DOI: http://dx.doi.org/10.12775/ EQUIL.2015.038

Michał Pilc*

Poznań University of Economics and Business, Poland

\section{What Determines the Reforms of Employment Protection Legislation? A Global Perspective}

JEL Classification: $D 02 ; D 78 ; J 08 ; J 32$

Keywords: political economics; employment protection legislation; labor law; labor market institutions; labor market policy

\begin{abstract}
The aim of this research was to identify the determinants of the employment protection legislation reforms in the global perspective. The study was based on the Labor Freedom index published by the Heritage Foundation, which allowed to include 179 countries in the research that were observed in the period 20032013. The conducted study has indicated that changes in GDP and the level of employment in industry may induce the introduction of labor reforms. The changes in the labor law also occurred to be correlated with the number of the nearly excluded from the labor market (the long-term unemployed and youth not in education, employment or training) and also with changes in the government expenditure. However, all these factors may lead to substantially various reform programs in particular countries due to the heterogeneous political pressure of the labor market interest groups and different governmental determination in introduction of the reforms.
\end{abstract} Toruń

Copyright Institute of Economic Research \& Polish Economic Society Branch in

Date of submission: February 26, 2015; date of acceptance: August 29, 2015

*Contact: michal.pilc@ue.poznan.pl, Department of Macroeconomics and Development Studies, Poznań University of Economics and Business, al. Niepodległości 10, 61-875 Poznań, Poland 


\section{Michat Pilc}

\section{Introduction}

The labor economics literature has generated a lively and continuously growing discussion concerning the role of labor market regulations for the labor market performance for the last three decades (Blanchard, 2006, pp. 13-35). Nowadays, there are no doubts that the situation on the labor market is dependent on its institutional framework (Lehmann \& Muravyev, 2012). In this context it is quite surprising that only a relatively small number of studies was aimed at answering the question of what determines the labor institutional framework in the particular countries.

The existing analyses in this area have been focused mainly on the OECD economies and were aimed primarily at explaining the differences among levels of various institutional indicators in the particular countries. In consequence, there is a need to develop this strand of research by conducting more analyses on determinants of the changes of the labor market institutions and by expanding the geographical scope of these studies. Therefore, the aim of this research is to identify the determinants of the employment protection legislation reforms around the world. The analysis is focused only on the employment protection due to data availability. The group of the analyzed countries comprises of 179 entities, while the time scope is 2003-2013.

In the next section, the methodology of the research is briefly described. Thereafter, an analysis of the determinants of labor market reforms based on the literature is presented. In the next section the general tendencies of the employment protection legislation changes in the research period are identified and analyzed. Thereafter, the results of the econometric investigation are presented. The last section concludes the article.

\section{Method of the Research}

Identification of the determinants of employment protection legislation reforms presented in this article was divided into two main steps. In the first step the critical analysis of the literature was conducted in order to select potential determinants of these reforms. In the next step the econometric investigation was executed in order to find which potential determinants are statistically significant. During this investigation the panel data models were used.

It was decided to use the index of Labor Freedom that is published by the Heritage Foundation (2014) as a quantitative measure of the employment protection legislation. It is an index that reflects various aspects of the 
legal and regulatory framework of a country's labor market, including regulations concerning minimum wages, laws inhibiting layoffs, severance requirements, and measurable regulatory restraints on hiring and hours worked. It takes values from 0 to 100 - the higher the value is, the lesser the guaranteed employment protection. Although the index tries to capture various labor market institutions, the description of its methodology suggests that it predominantly measures the strictness of the employment protection legislation (Heritage Foundation, 2014). It can also be noticed that it is similar to the EPL index published by the OECD (2014). Although the EPL is widely used in the literature, its values are regularly collected only for the OECD countries, whereas the Labor Freedom index has been assembled for 184 countries in 2014. It has been published from 2005 and refers to the period from 2004 to 2013. Therefore, the Labor Freedom index allows not only to analyze the short-term changes in the labor legislation, but also to identify the medium-term tendencies, because all the published values were estimated with the use of the same methodology.

All indicators that were analyzed as potential determinants of the employment legislation were derived from the World Development Indicators database (World Bank, 2014). It was decided to use this data set, because the measures for almost all countries investigated by the Heritage Foundation are published there (Taiwan is the only exception).

Not surprisingly, for such a broad set of countries the missing values occurred to be a significant obstacle during the study. Therefore, countries or years with almost no observations had to be removed. The obtained unbalanced panel data set comprised of 179 countries that were observed in the period 2003-2013.

\section{Insights From the Literature}

The institutions of the labor market may be defined as rules influencing the scope of choices available to the participants of this market with respect to the amount of work offered or demanded, and the level of wages (Boeri \& Van Ours, 2008, p. 3). Although these rules can be both formal and informal, most analyses focus only on the formal ones, due to data availability (and so it was done in the presented study).

The number of studies concerning the labor market institutions began to rise rapidly in the 80 's of the $20^{\text {th }}$ century (Blanchard, 2006, pp. 13-35). It was the time when many labor economists tried to explain the mechanism of the unemployment hysteresis occurrence. Labor market institutions were found not only to influence the hysteresis in a significant degree, but also 


\section{Michat Pilc}

allowed to explain why the strength of this effect is different in particular countries. Layard, Nickell and Jackman (2005, p. xxvii) state that labor market institutions indicators can explain around $55 \%$ of the unemployment volatility in highly developed states in years 1960-1990.

However, while there are no doubts now that the labor market institutions matter, it is quite surprising that relatively few researchers have given significant consideration to the question stated by Arpaia and Mourre (2005, pp. 17-18): 'why labor market institutions are as they are, and to what extent the current configuration of labor market institutions might be desirable despite sometimes their unfavorable impact on labor market performance'.

One possible answer to this question is that labor market institutions have their origins in the history of the country law or its culture (Arpaia and Mourre 2005, p. 18; Algan \& Cahuc, 2009). The second proposed explanation (Boeri \& Van Ours, 2008, p. 19) indicates that a competitive market for labor does not exist in practice. Informational asymmetries, externalities, search frictions and structural mismatches are the reasons why the labor market performance is usually far from the fully competitive market equilibrium. Thus, imposing institutions on the labor market may allow to attain at least the second-best outcome. The third view indicates that labor market institutions are introduced because they remain beneficial for the society, even if they hamper the labor market performance. For instance, Bertola and Koeniger (2004) show that strict employment protection and high unemployment benefits may be introduced in order to reduce labor income fluctuations in countries with under-developed financial systems, where consumer credit is relatively scarce. This argument can be especially significant for developing countries. Boeri and Van Ours (2008, p. 19) argue also that labor market institutions can increase the income equality effectively, which can also be perceived as socially beneficial. Finally, many labor market institutions exist because they are beneficial for some interest groups, especially for the employees who are the largest group of voters on the labor market (Saint-Paul, 1996, 2002; Boeri, Conde-Ruiz \& Galasso, 2003). Employees tend to exert pressure on the government to provide them protection against labor market risks at the cost of other labor market groups and labor productivity. This mechanism is present in every country, however its strength can be very different ${ }^{1}$. It should be stressed

\footnotetext{
${ }^{1}$ For instance, in order to ensure higher labor market flexibility many governments decided to liberalize regulations concerning the temporary employment. In the case of Germany (Eichhorst \& Marx, 2011), although the insiders had objected to such flexibilization in principle - once the reforms were in place - they reacted with decreasing their pressure on ensuring greater employment protection in order to strengthen their competitiveness relative
} 
that all these factors do not exclude one another, but operate complementarily, which leads to the substantial variety of institutional frameworks in the particular countries.

Therefore, it can be concluded that labor market institutions are reformed if one of the previously mentioned factors has changed. The work of Blanchard and Wolfers (2000) suggests that these changes can especially be a consequence of adverse macroeconomic shocks. Such a shock strongly affects the situation on the labor market, which induces the government to show its competence and react in some way (Saint-Paul, 1996, p. 276). Thus, the scope of reforms will be dependent on the preferences and determination of the government. For instance, it can offer more protection to employees. On the other hand, however, an adverse shock can decrease the political opposition of the insiders against labor reforms (Saint-Paul, 1996, p. 280), because they become more exposed to the risk of being dismissed, and in consequence, grow more interest in instruments that help the unemployed to find a job. In such a situation the government can increase the ALMP expenditure without changing the labor law (or even decide to introduce some liberalization of the law, for instance for temporary contracts). Therefore, it is not clear what the direction of labor reforms will be in reaction to such a shock, because it will depend on the political strength of particular groups on the labor market, on their preferences, on the scale and nature of the shock, and on the government decisions.

These shocks do not need to be demand shocks only. Changes in the level of competition on the goods market (caused for example by the technological progress or by opening to new international markets) may also lead to changes in the labor market institutions (Boeri, 2005). When the level of competition rises, existing labor regulations cause higher forgone efficiency and, in consequence, the difference between achieved social welfare and potential social welfare is higher. In such a situation, it would be economically desirable to liberalize the labor regulations, which - however - could be politically unattainable due to the opposition of some groups of employees (Boeri \& Van Ours, 2008, p. 21). Thus, the government may only decide to propose a two-tier reform (Boeri \& Garibaldi, 2006) which will relax the labor regulations only for some groups (for instance temporary employees).

Paradoxically, this opposition may be so strong that it will induce the government to deliberately introduce some labor protective institutions at the cost of social welfare. The government can, for example, offer some

to flexible workers. On the other hand, relaxing regulations of the temporary contracts in Spain (Dolado, García-Serrano, \& Jimeno, 2002) increased the pressure from permanent employees to secure their posts, which resulted in formulation of the dual market. 
form of compensation to the insiders in order to gain their support for the reform (Drazen, 2002, pp. 624-625). For instance, it may create a special ALMP program or increase the level of unemployment benefits. The government may also decide to implement reforms gradually if various interest groups are against some parts of the reform only (Drazen, 2002, pp. 626632). This 'divide and conquer' strategy will extend the time span between a macroeconomic shock and labor market changes, and in fact disturb the relationship between these two phenomena.

Although the conducted review of the literature was succinct, it allows to conclude that labor market institutions reforms can be triggered by a broad set of factors among which, presumably, the most important are adverse demand shocks that significantly affect the situation on the labor market, and positive supply shocks, which allow to increase the labor productivity. However, due to the political opposition of the insiders, these changes can have various scope, time of implementation and even different direction ${ }^{2}$.

Therefore, it can be concluded that although the literature suggests many potential determinants of labor reforms, it does not give clear-cut conclusions concerning their significance and strength of their influence. Thus, there is a need to identify these determinants empirically and to assess their average impact, which will be the goal of the following sections.

\section{Global Tendencies in the Employment Protection Reforms}

The year to year changes in global GDP, unemployment rate and Labor Freedom index are presented on Figure 1. The data indicates that employment protection legislation in the world was (on average) being liberalized slightly in years 2006-2009, so in the time when many economies were experiencing growth.

\footnotetext{
${ }^{2}$ Thus, it is not surprising that labor regulations are changed relatively often. Boeri and Van Ours (2008, p. 23) state that in the EU countries in years 1986-2005, on average, more than 1.2 labor reforms were conducted per year and country, however more than $90 \%$ of the reforms can be perceived as marginal.
} 
Figure 1. Year to year changes in GDP, unemployment rate and Labor Freedom index (global averages, last year $=100$ )

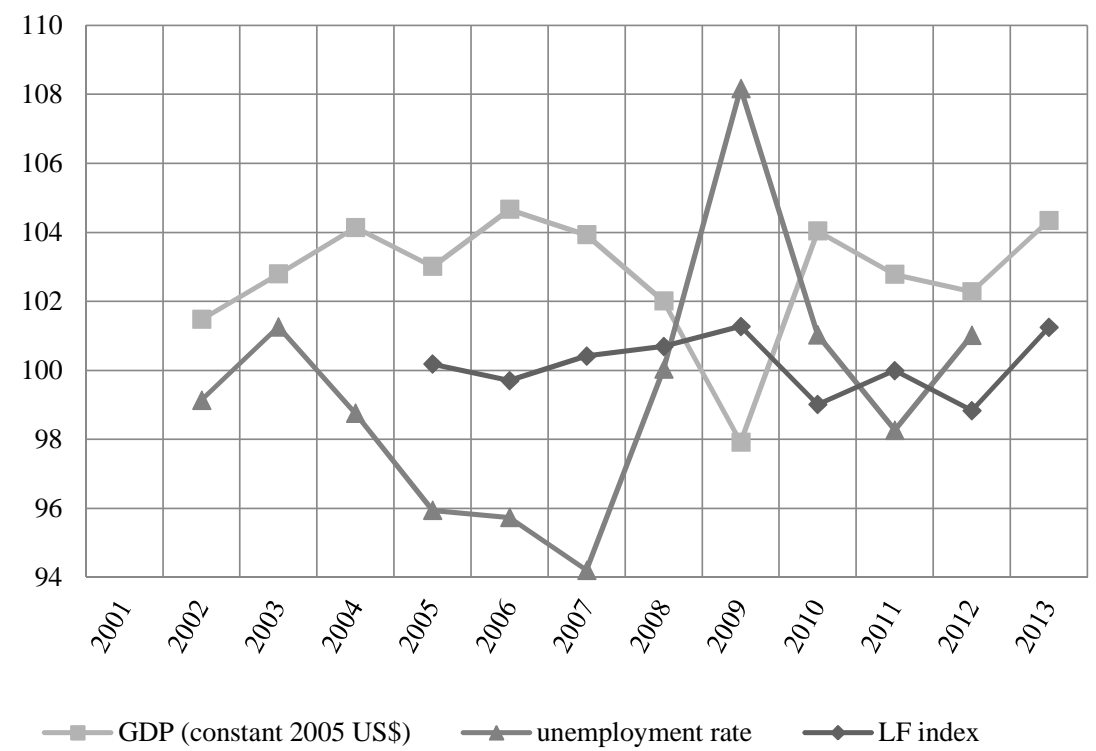

Note: the values of the Labor Freedom index are given for the concerned year, not for the year of their publication.

Source: own elaboration based on the Heritage Foundation (2014) and World Bank (2014).

That process was stopped in 2009 when the global unemployment rate reached its peak and the world economy fell into recession. The collected data indicates that between 2010 and 2012 the mean world value of the Labor Freedom index was decreasing. Therefore, it can be concluded that the governments decided rather to support the insiders and strengthen the employment protection in reaction to the adverse shock. It probably resulted in more difficulties in decreasing the unemployment rate during the following recovery.

The year to year changes in the Labor Freedom index can be treated as an indicator of the short-term employment protection reforms. Additionally, we also calculate an index of the long-term reforms, which is aimed at representing the main tendency of labor reforms in each of the analyzed states with the use of a single variable. It is calculated as a relative difference between the largest and the smallest values of the Labor Freedom index for each particular country. 
More precisely, for each country we first identified the years when the minimum and the maximum value of the Labor Freedom index were observed (they were denoted as $t \_$min and $t \_$max respectively). Secondly, the long-term reform (LTR) index was calculated as ${ }^{3}$ :

$$
L T R= \begin{cases}\max \left(L F I_{t}\right) / \min \left(L F I_{t}\right) \cdot 100 \%, & \text { if } t_{\max }>t_{\min } \\ \min \left(L F I_{t}\right) / \max \left(L F I_{t}\right) \cdot 100 \%, & \text { if } t_{\max } \leq t_{\min }\end{cases}
$$

where $t$ means time and LFI represents Labor Freedom index. The absolute difference of $t \_$min and $t \_m a x$ indicates the duration of the long-term reform. Therefore, whenever the long-term reform index takes a value below $100 \%$, it means that the analyzed country has strengthened the labor protection (and in consequence the Labor Freedom index has fallen), whereas a value above $100 \%$ means that the labor law regulations have been liberalized. If the index had a value equal to $100 \%$, it would mean that the analyzed country did not change labor regulations at all in the analyzed period (then the maximum value would be equal to minimum).

The values of the long-term reform index are presented on Figure 2. As it can be noticed, the durability of labor law reforms is significantly diversified, however, generally shorter duration is more probable than longer one. The modal duration is 3 years, which may indicate that more governments prefer to apply the gradual rather than the immediate approach to employment protection reforms. Although the average value of the long-term index was equal to $102.8 \%$, the results reveal that in $58.3 \%$ of countries the labor freedom was limited (in the case of $18.3 \%$ states by more than $20 \%$ ), while only in $41.7 \%$ the employment regulations were liberalized (in the case of $18.9 \%$ states by more than $20 \%$ ). One may conjecture that the estimation of the average value was biased by 3 outliners (for Bahrain, Burma and Libya respectively) that are clearly visible on Figure 2 . However, even after their exclusion the average values of the long-term reform indices higher than

\footnotetext{
${ }^{3}$ It should be added that the lowest value of the Labor Freedom index in the data set was equal to 20 , therefore there was no risk of dividing by zero. Of course, one can imagine many other indicators than can represent the long-term reforms. It was decided to use this one, because it assigns single value for each country and ensures that every country is equally represented in the data set. Moreover, this index allows to capture the most radical reform for each country, both gradual and immediate.
} 
$100 \%$ was proportionally greater than analogous average for the values of the index lower than $100 \%$ (122\% to $83 \%$ respectively). This indicates that the average long-term labor law liberalization was greater than the average long-term labor freedom limitation by 5 percentage points ${ }^{4}$.

Figure 2. The scale and durability of the long-term reforms in the analyzed countries

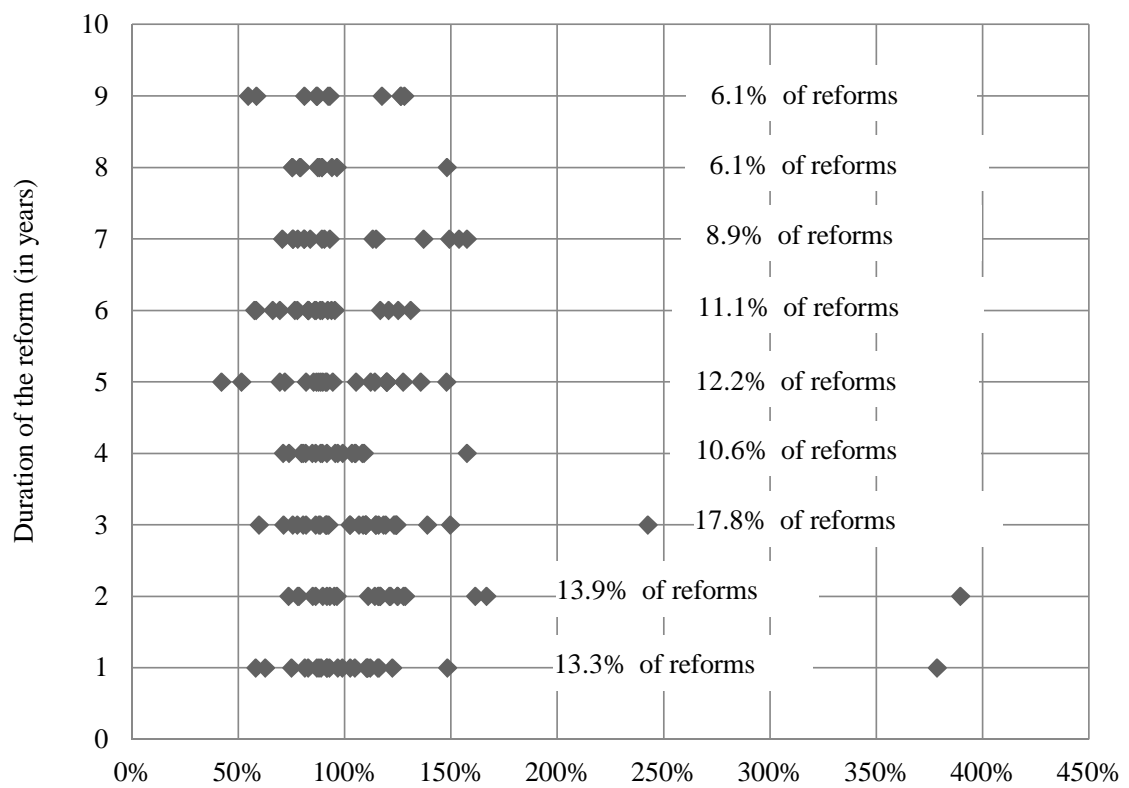

Scale of the long-term reforms

Source: own calculations based on the Heritage Foundation (2014).

These result can be seen in the perspective of political opposition from employees against labor law liberalization. The calculated indicators suggest that governments often decide to postpone the reforms that relax the employment protection. However, when the reforms are conducted, they are deeper than the typical changes that increase the level of that protection.

\footnotetext{
${ }^{4}$ It was calculated as: $(122-100)-(100-83)=5$
} 


\section{Econometric Analysis}

The empirical analysis was focused on identifying determinants of the short-term labor law reforms that were measured by the year to year changes in the Labor Freedom index. Although a separate analysis was also conducted for the long-term reforms, it was decided not to present it, because it did not allow to identify any significant determinants of the labor market reforms, which was probably a consequence of a relatively small number of observations (one value for each country).

The empirical analysis for the short-term reforms was conducted in two steps. Firstly, a set of unbalanced panel models was estimated for all gathered indicators from the World Bank (2014) that were analyzed as potential determinants of the labor law reforms. During that step for all independent variables the indices of a year to year change were calculated and were added to the data set ${ }^{5}$. Secondly, for the selected variables that occurred to be significant in the first step two balanced data set were constructed ${ }^{6}$, which allowed to perform the final analysis. One of the balanced data set comprised all significant variables, but at the cost of relatively small number of observations, while in the second one a few variables were dropped, which substantially increased the number of observations. Such an approach allowed also to verify the results with different data sets.

The models were estimated as the pooled, fixed effects (the within estimator) and random effects (Swamy \& Arora, 1972) ${ }^{7}$. The decision which model type should be used was based on the Hausman, Breusch-Pagan and F tests. Initially, the Breusch-Pagan was conducted which indicated whether there was an unobserved heterogeneity in the model (if there was not, the pooled model was estimated). Then, the Hausman test allowed to decide whether the random effects model could be estimated. If not, it was checked with the F test whether the fixed effects model is justified. In most cases these tests unequivocally indicated which model should be employed (pooled, fixed or random). In few cases, where the Breusch-Pagan and $\mathrm{F}$ tests showed that it is justified to estimate both pooled and fixed model, it was decided to present the results of both specifications.

\footnotetext{
${ }^{5}$ Thus all analyzed indicators were expressed both in levels and in indices.

${ }^{6}$ Singular missing values for particular variables were filled with linear interpolation. However, if the multiple missing values were noticed, it was decided to drop the particular country or year from the data set.

${ }^{7}$ The models were also estimated with the use of the system GMM estimator (Arellano \& Bover, 1995; Blundell \& Bond, 1998). However, it occurred that in all estimated models the lagged values of the dependent variable were insignificant, therefore it was decided not to use the GMM estimator. Moreover, obtaining such results limits the potential problems with endogeneity.
} 
It was decided to use the estimator of the covariance matrix proposed by Arellano (1987), which is designed to handle both heteroscedasticity and autocorrelation in the data sets consisting of many units observed in relatively few periods. The variables were not logarithmically transformed, which is not a rare approach in empirical analysis concerning the labor market institutions (Nickell, 1997; Cazes \& Nesporova, 2003; Lehmann \& Muravyev 2012). It should be added that the models reestimated with the logarithmically transformed variables led to the same conclusions, albeit their fit to the data occurred to be generally worse.

As the theoretical models do not specify accurately which indicators should have a decisive impact on the labor market reforms, in the preliminary analysis a broad set of various variables, characterizing mainly the situation on the labor market and different economic shocks, was employed into the analysis. Many of them occurred to be insignificant. The group of irrelevant variables comprised of: labor force participation rate, unemployment rate, youth unemployment rate, age dependency ratio (separately for younger and older dependents), employment to population ratio, GDP per capita, consumption expenditure, exports of goods and services, current account balance, foreign direct investments, market capitalization, and central government debt.

Surprisingly, only a few analyzed variables occurred to be significantly correlated with the year to year changes in the Labor Freedom index. The selected results for these variables are presented in Tables 2, 3 and 4, whereas their short description is shown in Table 1.The results of the unbalanced panel estimation (Table 2) confirm that in the analyzed period more countries decided to strengthen their labor protection legislation. It is indicated by the negative and significant parameter for the $L F I$ variable. It also informs that the higher the level of labor freedom, the greater the pressure to limit it. A surprising result was obtained for the unemployment rate which occurred to be insignificant determinant of labor law reforms.

As far as the GDP growth is concerned, it was found that the better the economic situation is, the stronger the tendency to liberalize labor regulations (Model 2). Although such a result is in line with previously derived conclusion (see Figure 1), it has to be stated that this relationship loses its significance if the LFI and yy_world_LFI are added to the model (Model $3)$. Moreover, adding the measure of the market capitalization, which can also be seen as an indicator of the current economic situation, did not help to explain the scale of labor law reforms. 
Table 1. Description of variables presented in the econometric analysis

\begin{tabular}{|c|c|c|}
\hline Variable & Short description & Obs. \\
\hline \multicolumn{3}{|c|}{ Dependent variable } \\
\hline$y y_{-} L F I$ & A year to year change in the Labor Freedom Index & 1487 \\
\hline \multicolumn{3}{|c|}{ Independent variables } \\
\hline$L F I$ & The Labor Freedom Index (scale 0-100) & 1667 \\
\hline$y y \_w o r l d \_L F I$ & $\begin{array}{c}\text { A year to year change in the global average of the Labor } \\
\text { Freedom Index }\end{array}$ & 9 \\
\hline$u$ & $\begin{array}{l}\text { Unemployment rate (ILO estimate, } \\
\text { alternatively national estimate) }\end{array}$ & 1524 \\
\hline emp_ind & Employment in industry (\% of total employment) & 835 \\
\hline u_long & Long-term unemployment ( $\%$ of tot. unemp.) & 544 \\
\hline neet & $\begin{array}{l}\text { Share of youth not in education, employment or training } \\
\text { (\% of youth population) }\end{array}$ & 371 \\
\hline$y y \_g d p$ & A year to year change in GDP (constant 2005 US\$) & 1760 \\
\hline market_cap & $\begin{array}{c}\text { Market capitalization of listed companies } \\
\text { (\% of GDP) }\end{array}$ & 959 \\
\hline gov_exp & $\begin{array}{l}\text { General government final consumption expenditure (\% of } \\
\text { GDP) }\end{array}$ & 1535 \\
\hline
\end{tabular}

Note: a prefix 'yy_' before the variable name means that it is an index of the year to year change of that variable, where previous year $=100$.

Source: own elaboration based on the Heritage Foundation (2014) and World Bank (2014).

Interesting results were obtained for the neet and $u_{-}$long variables (Model 5 and 6). They indicate that the larger the group of excluded (or nearly excluded) from the labor market is, the greater the pressure to liberalize the labor law. However, this conclusion is in fact limited mainly to the highly developed countries due to the large amount of missing values for developing countries for the neet and $u_{-}$long variables. 
Table 2. Selected results obtained for the unbalanced panel

\begin{tabular}{|c|c|c|c|c|c|c|}
\hline & Mod. 1 & Mod. 2 & Mod. 3 & Mod. 4 & Mod. 5 & Mod. 6 \\
\hline Intercept & & $\begin{array}{l}91.002^{* * *} \\
(5.148)\end{array}$ & & & $\begin{array}{l}98.373^{* * *} \\
(0.689)\end{array}$ & $\begin{array}{l}91.000^{* * *} \\
(7.281)^{2}\end{array}$ \\
\hline LFI (-1) & $\begin{array}{l}-0.598^{\text {*** }} \\
(0.053)^{* * *}\end{array}$ & & $\begin{array}{l}-0.614^{* * * *} \\
(0.052)\end{array}$ & $\begin{array}{l}-0.614^{* * *} \\
(0.065)\end{array}$ & & \\
\hline yy_world_LFI & $\begin{array}{l}1.166^{* * *} \\
(0.401)\end{array}$ & & $\begin{array}{l}0.799^{* * *} \\
(0.262)\end{array}$ & $\begin{array}{l}0.529^{*} \\
(0.296)\end{array}$ & & \\
\hline $\mathrm{u}(-1)$ & $\begin{array}{l}0.150 \\
(0.119)\end{array}$ & & & & & \\
\hline yy_gdp (-1) & & $\begin{array}{l}0.087^{*} \\
(0.050)\end{array}$ & $\begin{array}{l}-0.009 \\
(0.064)\end{array}$ & & & \\
\hline market_cap (-1) & & & & $\begin{array}{l}0.025 \\
(0.019)\end{array}$ & & \\
\hline neet $(-1)$ & & & & & $\begin{array}{l}0.099^{* *} \\
(0.042)\end{array}$ & $\begin{array}{l}0.069^{*} \\
(0.035)\end{array}$ \\
\hline u_long $(-1)$ & & & & & & $\begin{array}{l}0.032^{* *} \\
(0.016)\end{array}$ \\
\hline yy_gov_exp (-1) & & & & & & $\begin{array}{l}0.069 \\
(0.068) \\
\end{array}$ \\
\hline$\overline{\mathrm{R}^{2}}$ & 0.097 & 0.027 & 0.171 & 0.177 & 0.196 & 0.411 \\
\hline Adjusted $\mathrm{R}^{2}$ & 0.086 & 0.026 & 0.150 & 0.156 & 0.195 & 0.407 \\
\hline Model type & $\mathrm{FE}$ & $\mathrm{RE}$ & $\mathrm{FE}$ & $\mathrm{FE}$ & $\mathrm{RE}$ & $\mathrm{RE}$ \\
\hline $\begin{array}{l}\text { Number } \\
\text { of observations }\end{array}$ & 1433 & 1463 & 1463 & 946 & 370 & 338 \\
\hline $\begin{array}{l}\text { Number } \\
\text { of countries }\end{array}$ & 173 & 179 & 179 & 110 & 67 & 47 \\
\hline Time effects & no & yes & no & no & yes & yes \\
\hline
\end{tabular}

Note: the '(-1)' symbol attached to almost all independent variables means that they were lagged by one year. Standard errors are reported in parentheses. Asterisks denote significance levels: $* * *-1 \%, * *-5 \%$ and $*-10 \%$.

Source: own estimates.

The results for the first balanced panel data set that consists of 96 countries and 768 yearly observations are presented in Table 3. It can be noticed that Model 7 has the same set of variables as Model 8 (the same applies to Model 10 and 11), which is a consequence of the fact that the BreuschPagan and $\mathrm{F}$ tests gave unequivocal results concerning the need to introduce dummy variables for the countries while Model 9 and 12 were ob- 


\section{Michat Pilc}

tained as a result of the process of sequential elimination of insignificant variables from Model 8 and 11.

Table 3. Results obtained for the first balanced panel

\begin{tabular}{|c|c|c|c|c|c|c|}
\hline & Mod. 7 & Mod. 8 & Mod. 9 & Mod. 10 & Mod. 11 & Mod. 12 \\
\hline Intercept & $\begin{array}{l}49.540 \\
(45.116)\end{array}$ & & & $\begin{array}{l}47.207 \\
(44.483)\end{array}$ & & \\
\hline LFI(-1) & $\begin{array}{l}-0.034^{*} \\
(0.020)\end{array}$ & $\begin{array}{l}-0.534^{* * *} \\
(0.061)\end{array}$ & $\begin{array}{l}-0.537^{* * *} \\
(0.058)\end{array}$ & $\begin{array}{l}-0.034^{*} \\
(0.018)\end{array}$ & $\begin{array}{l}-0.522^{* * *} \\
(0.068)\end{array}$ & $\begin{array}{l}-0.526^{* * *} \\
(0.066)\end{array}$ \\
\hline yy_world_LFI & $\begin{array}{l}0.520 \\
(0.446)\end{array}$ & $\begin{array}{l}0.359 \\
(0.410)\end{array}$ & & $\begin{array}{l}0.524 \\
(0.443)\end{array}$ & $\begin{array}{l}0.597 \\
(0.459)\end{array}$ & \\
\hline yy_gdp (-1) & $\begin{array}{l}0.060 \\
(0.068)\end{array}$ & $\begin{array}{l}-0.091 \\
(0.128)\end{array}$ & & $\begin{array}{l}0.073 \\
(0.071)\end{array}$ & $\begin{array}{l}-0.033 \\
(0.099)\end{array}$ & \\
\hline market_cap (-1) & $\begin{array}{l}-0.000 \\
(0.004)\end{array}$ & $\begin{array}{l}0.023 \\
(0.020)\end{array}$ & & & & \\
\hline yy_market_cap (-1) & $\begin{array}{l}0.006 \\
(0.014)\end{array}$ & $\begin{array}{l}0.004 \\
(0.012)\end{array}$ & & $\begin{array}{l}0.006 \\
(0.013)\end{array}$ & $\begin{array}{l}0.007 \\
(0.013)\end{array}$ & \\
\hline gov_exp (-1) & $\begin{array}{l}-0.037 \\
(0.041)\end{array}$ & $\begin{array}{l}-0.407^{\text {** }} \\
(0.171)\end{array}$ & $\begin{array}{l}-0.544^{*} \\
(0.22)\end{array}$ & & & \\
\hline yy_gov_exp (-1) & $\begin{array}{l}-0.055 \\
(0.074)\end{array}$ & $\begin{array}{l}-0.029 \\
(0.042)\end{array}$ & & $\begin{array}{l}-0.055 \\
(0.069) \\
\end{array}$ & $\begin{array}{l}-0.041^{* * * *} \\
(0.014)\end{array}$ & $\begin{array}{l}-0.048^{* * *} \\
(0.011)\end{array}$ \\
\hline$\overline{\mathrm{R}^{2}}$ & 0.030 & 0.160 & 0.141 & 0.030 & 0.147 & 0.200 \\
\hline Adjusted $\mathrm{R}^{2}$ & 0.030 & 0.139 & 0.123 & 0.030 & 0.128 & 0.170 \\
\hline Model type & pooled & $\mathrm{FE}$ & $\mathrm{FE}$ & pooled & $\mathrm{FE}$ & FE \\
\hline $\begin{array}{l}\text { Number } \\
\text { of observations }\end{array}$ & 768 & 768 & 768 & 768 & 768 & 768 \\
\hline $\begin{array}{l}\text { Number of } \\
\text { countries }\end{array}$ & 96 & 96 & 96 & 96 & 96 & 96 \\
\hline Time effects & no & no & no & no & no & no \\
\hline
\end{tabular}

Note: the '(-1)' symbol attached to almost all independent variables means that they were lagged by one year. Standard errors are reported in parentheses. Asterisks denote significance levels: $* * *-1 \%, * *-5 \%$ and $*-10 \%$.

Source: own estimates. 
The results obtained for this panel also did not indicate that changes in GDP are significant determinants of the changes in the Labor Freedom index. Different conclusions can be derived for the government expenditure. The estimates indicate that the higher these expenditures are (or their dynamics), the stronger is the pressure to strengthen the labor protection. Probably, changes in both variables can be seen as two elements of the same decision. In reaction to an adverse shock the government might both increase the public spending and strengthen the labor protection.

The results for the second balanced panel that consists of 37 countries and 296 observations are presented in Table 4. Here also initial equations are presented for two different specifications due to the unequivocal results for the Breusch-Pagan and F tests. Quite surprisingly, the previously derived conclusions concerning the government expenditure and excluded groups from the labor market did not found confirmation in this reduced data set. It may indicate that previously identified relationships have heterogeneous relevance for different groups of countries. Such a result is less surprising if it is remembered that (and as the literature suggests) the impact of the analyzed determinants may be dependent on the political strength of particular groups on the labor market and also on the government's preferences and determination. All these political factors are not directly observed (especially globally), therefore it was not possible to analyze their potential interactions with the identified determinants. However, it may be concluded that these factors play different role in particular countries, which in consequence led to obtaining unequivocal results.

Table 4. Results obtained for the second balanced panel

\begin{tabular}{l|llllll}
\hline & Mod. 13 & Mod. 14 & Mod. 15 & Mod. 16 & Mod. 17 & Mod. 18 \\
\hline \multirow{2}{*}{ Intercept } & $190.6^{* * * *}$ & & & $169.12^{* * *}$ & $165.21^{* * *}$ & $110.9^{* * * *}$ \\
& $(47.833)$ & & & $(43.919)$ & $(62.187)$ & $(8.731)$ \\
LFI(-1) & 0.000 & $-0.441^{* * *}$ & $-0.440^{* * *}$ & -0.007 & -0.006 & \\
& $(0.017)$ & $(0.108)$ & $(0.100)$ & $(0.015)$ & $(0.015)$ & \\
yy_world_LFI & $-0.999^{* *}$ & -0.831 & & -0.796 & -0.763 & \\
& $(0.550)$ & $(0.627)$ & & $(0.524)$ & $(0.689)$ & \\
yy_gdp (-1) & 0.210 & 0.221 & & 0.208 & 0.204 & \\
& $(0.166)$ & $(0.189)$ & & $(0.172)$ & $(0.176)$ & \\
market_cap (-1) & 0.004 & 0.011 & $0.021^{* *}$ & & & \\
& $(0.007)$ & $(0.017)$ & $(0.009)$ & & & \\
yy_market_cap (-1) & 0.007 & 0.003 & & 0.011 & 0.011 & \\
& $(0.011)$ & $(0.015)$ & & $(0.009)$ & $(0.012)$ &
\end{tabular}


Table 4 continued

\begin{tabular}{l|llllll}
\hline & Mod. 13 & Mod. 14 & Mod. 15 & Mod. 16 & Mod. 17 & Mod. 18 \\
\hline gov_exp (-1) & -0.042 & -0.006 & & & \\
& $(0.055)$ & $(0.507)$ & & & \\
yy_gov_exp (-1) & 0.054 & 0.054 & & 0.043 & 0.048 & \\
& $(0.093)$ & $(0.167)$ & & $(0.083)$ & $(0.083)$ & \\
emp_ind (-1) & $0.211^{* *}$ & 0.392 & & & & \\
& $(0.088)$ & $(0.330)$ & & & & \\
yy_emp_ind (-1) & $-0.238^{* * *}$ & $-0.268^{* * *}$ & $-0.164^{*}$ & $-0.164^{*}$ & $-0.164^{*}$ & $-0.161^{*}$ \\
& $(0.085)$ & $(0.098)$ & $(0.088)$ & $(0.093)$ & $(0.093)$ & $(0.088)$ \\
u_long (-1) & -0.019 & -0.026 & & & & \\
yy_u_long (-1) & $(0.018)$ & $(0.065)$ & & & & \\
& 0.005 & 0.002 & & -0.003 & -0.005 & \\
neet (-1) & $(0.009)$ & $(0.013)$ & & $(0.009)$ & $(0.010)$ & \\
& 0.017 & 0.234 & & & & \\
yy_neet (-1) & $(0.033)$ & $(0.311)$ & & & & \\
\hline R & -0.001 & -0.012 & & 0.006 & 0.011 & \\
Adjusted R & $(0.028)$ & $(0.029)$ & & $(0.029)$ & $(0.030)$ & \\
Model type & 0.072 & 0.154 & 0.124 & 0.041 & 0.030 & 0.02 \\
Number & 0.069 & 0.128 & 0.107 & 0.039 & 0.029 & 0.02 \\
of observations & pooled & FE & FE & pooled & RE & RE \\
Number of countries & 296 & 296 & 296 & 296 & 296 & 296 \\
Time effects & 37 & 37 & 37 & 37 & 37 & 37 \\
\hline & no & no & no & no & yes & yes \\
\hline
\end{tabular}

Note: the '(-1)' symbol attached to almost all independent variables means that they were lagged by one year. Standard errors are reported in parentheses. Asterisks denote significance levels: $* * *-1 \%, * *-5 \%$ and $*-10 \%$.

Source: own estimates.

The results presented in Table 4 indicate, however, that the level of employment in industry (as a percentage of total employment) and changes of that level can be important determinants of labor law reforms. Probably, the theoretical analysis conducted by Boeri (2005) can help to explain this relationship. A stronger industry sector should result in greater exposure to supply shocks. Thus, positive supply shocks lead to higher forgone efficiency (when the labor regulations are not changed), which causes pressure to liberalize the labor law. This liberalization is, however, opposed by the industry workers. Therefore, it is not surprising that increase in the number 
of these workers provides them with greater political strength and may result in reinforcement of their protection. Moreover, Model 15 indicated that the market capitalization of listed companies could be an important factor, however this relation was not confirmed by other specifications.

\section{Conclusions}

The aim of this research was to identify the determinants of the employment protection legislation reforms around the world. Critical analysis of the literature indicated that macroeconomic shocks could be incentives to these reforms, especially the adverse shocks (that worsen the situation on the labor market). However, also the positive supply shocks can trigger reforms, because an increase in labor productivity causes that current employment protection regulations result in higher forgone efficiency. However, these incentives may lead to different governmental decisions, since the government also has to include the political pressure from various interest groups on the labor market, especially the employees. In consequence, the initiated reforms can have various scope, time of implementation and even different direction.

The empirical analysis was conducted for 179 countries with the use of the Labor Freedom index published by the Heritage Foundation. The initial analysis of the collected data revealed that governments less often decide to conduct reforms that relax the employment protection. However, when the reforms are initiated, they are usually deeper than the typical changes that increase the level of that protection. It was also found that in years 20062009 , when the world economic situation was promising, most governments decided to liberalize the labor law. However, this tendency was reversed in reaction to the global recession in 2009 when governments generally decided to strengthen the protection of employees.

The econometric investigation allowed to identify a few indicators that can initiate the labor law reforms. It was found that changes in GDP and the level of employment in industry may be such factors. Labor law reforms may also depend on the number of the nearly excluded from the labor market (long-term unemployed and the youth not in education, employment or training). The changes in employment protection also occurred to be correlated with changes in the government expenditure.

However, these results were not confirmed in all models, which may be a consequence of omitting potentially important factors, i.e. the political strength of particular groups on the labor market and the determination of government to implement the reforms, because they are not directly ob- 
servable. The low level of the coefficient of determination in almost all estimated equations indicates that these omitted factors may play a substantial role in explaining the changes in the labor law. Moreover, it is also possible that the influence of particular variables may be different in various groups of countries (distinguished on the basis of income per capita, geographical location, form of government, etc.). Therefore, there is a need to continue the research in this field, especially in order to assess the strength of political factors that may affect the labor market reforms. It is also advised to continue these analyses with the use of other indicators of labor market institutions in order to verify conclusions obtained in the presented research.

\section{References}

Algan, Y., \& Cahuc, P. (2009). Civic Virtue and Labor Market Institutions. American Economic Journal: Macroeconomics, 1(1). DOI: http://dx.doi.org/10. 1257/mac.1.1.111.

Arellano, M. (1987). Computing Robust Standard Errors for Within Group Estimators. Oxford Bulletin of Economics and Statistics, 49.

Arellano, M., \& Bover, O. (1995). Another look at the instrumental variable estimation of error-components models. Journal of Econometrics, 68(1). DOI: http://dx.doi.org/10.1016/0304-4076(94)01642-D.

Arpaia, A., \& Mourre, G. (2005). Labour Market Institutions and Labour Market Performance: A Survey of the Literature. European Commission Economic Papers, 238.

Bertola, G., \& Koeniger, W. (2004). Consumption smoothing and the structure of labor and credit markets. IZA Discussion Paper, 1052.

Blanchard, O. (2006). European unemployment: the evolution of facts and ideas. Economic policy, 21(45). DOI: http://dx.doi.org/10.1111/j.1468-0327.2006 .00153.x.

Blanchard, O., \& Wolfers, J. (2000). The role of shocks and institutions in the rise of European unemployment: the aggregate evidence. The Economic Journal, 110(462). DOI: http://dx.doi.org/10.1111/1468-0297.00518.

Blundell, R., \& Bond, S. (1998). Initial conditions and moment restrictions in dynamic panel data models. Journal of Econometrics, 87. DOI: http://dx.doi.org /10. 1016/S0304-4076(98)00009-8.

Boeri, T. (2005). Reforming Labour and Product Markets: Some Lessons from Two Decades of Experiments in Europe. IMF Working Paper, 05/97.

Boeri, T., Conde-Ruiz, J. I., \& Galasso, V. (2003). Protecting Against Labour Market Risk: Employment Protection or Unemployment Benefits? IZA Discussion Paper, 834. 
Boeri, T., \& Garibaldi, P. (2006). Two tier reforms of employment protection: A honeymoon effect? Economic Journal, 17. DOI: http://dx.doi.org/10.1111/ j.1468-0297.2007.02060.x.

Boeri, T., \& Van Ours, J. (2008). The Economics of Imperfect Labor Markets. Princeton: Princeton University Press.

Cazes, S., \& Nesporova, A. (2003). Labour Markets in Transition: Balancing Flexibility and Security in Central and Eastern Europe, Geneva: ILO. DOI: http://dx.doi.org/10.3917/reof.075.0023.

Dolado, J. J., García-Serrano, C., \& Jimeno, J. F. (2002). Drawing lessons from the boom of temporary jobs in Spain. The Economic Journal, 112(480). DOI: http://dx.doi.org/10.3917/reof.075.0023.

Drazen, A. (2002). Political economy in macroeconomics. Princeton: Princeton University Press.

Eichhorst, W., \& Marx, P. (2011). Reforming German labour market institutions: A dual path to flexibility. Journal of European Social Policy, 21(1). DOI: http://dx.doi.org/10.1177/0958928710385731.

Heritage Foundation (2014). Labor Freedom. Retrieved from http://www.heritage. org/index/labor-freedom (19.11.2014).

Layard, R., Nickell, S., \& Jackman, R. (2005). Unemployment. Macroeconomic Performance and the Labour Market, 2nd ed. Oxford: Oxford University Press.

Lehmann, H., \& Muravyev, A. (2012). Labor Market Institutions and Labor Market Performance: What Can We Learn from Transition Countries? Economics of Transition, 20(2). DOI: http://dx.doi.org/10.2139/ssrn.1681525.

Nickell, S. (1997). Unemployment and labor market rigidities: Europe versus North America, Journal of Economic Perspectives, 11(3). DOI: http://dx.doi.org/10.1257/jep.11.3.55.

OECD (2014). OECD Indicators of Employment Protection. Retrieved from http://www.oecd.org/employment/emp/oecdindicatorsofemploymentprotection. htm (29.12.2014).

Saint-Paul, G. (1996). Exploring the Political Economy of Labour Market Institutions. Economic Policy, 11(23).

Saint-Paul, G. (2002). The Political Economy of Employment Protection. Journal of Political Economy, 110(3).

Swamy P., Arora S. (1972). The Exact Finite Sample Properties of the Estimators of Coefficients in the Error Components Regression Models. Econometrica, 40. DOI: http://dx.doi.org/10.2307/1909405.

World Bank (2014). World Development Indicators database. Retrieved from http://data.worldbank.org/products/wdi (21.11.2014). 
